HABITAT, 29 (1), 2018, 25-32

DOI: 10.21776/ub.habitat.2018.029.1.3

\title{
Niat Individu Mengkonsumsi Sayur Organik di Kelurahan Sawojajar Kota Malang
}

\section{Individual Intention to Consume Organic Vegetables in Sawojajar Malang City}

\author{
Surya Delviola ${ }^{1^{*}}$, Ratya Anindita ${ }^{2}$, Rini Mutisari ${ }^{2}$ \\ Jurusan Sosial Ekonomi, Fakultas Pertanian, Universitas Brawijaya, Jl. Veteran, Malang (65145) \\ Received: 26 July 2018; Revised: 31 August 2018; Accepted: 31 August 2018
}

\begin{abstract}
ABSTRAK
Tren baru di masyarakat dunia menjadikan masyarakat sadar akan gaya hidup sehat, sehingga mulai memperhatikan bahan pangan yang akan dikonsumsi. Sayur organik merupakan salah satu bahan pangan alami yang tidak terkontaminasi bahan kimia berbahaya, namun tindakan pembelian masyarakat Indonesia terhadap sayur organik masih rendah meskipun memiliki minat yang tinggi terhadap sayur organik, sehingga tidak mengikuti tren dunia. Tujuan penelitian ini adalah untuk menganalisis faktorfaktor yang mempengaruhi niat individu dalam mengkonsumsi sayur organik dengan menggunakan Theory of Planned Behavior (TPB). Niat individu dalam TPB dipengaruhi oleh tiga faktor yaitu sikap, norma subjektif dan persepsi kontrol perilaku. Penelitian dilakukan pada ibu-ibu yang sedang melakukan kegiatan pembelian sayur organik di Toko Sayur dan Buah Dapur Ku, Kelurahan Sawojajar, Kota Malang dengan menggunakan metode analisis Structural Equation Modelling - Partial Least Square (SEM PLS). Hasil penelitian ini menunjukkan bahwa variabel sikap, norma subjektif dan persepsi kontrol perilaku memberikan pengaruh yang signifikan terhadap niat individu dalam mengkonsumsi sayur organik dengan nilai $p$-value $<0,001$. Nilai $R$-square pada penelitian ini adalah sebesar $51 \%$ berarti bahwa pengaruh variabel sikap, norma subjektif dan persepsi kontrol perilaku terhadap niat pembelian sayur organik sebesar 51\% sedangkan sisanya 49\% dipengaruhi variabel lain di luar model.
\end{abstract}

Kata kunci: niat; sayur organik; Theory of Planned Behavior; Partial Least Square (PLS)

\begin{abstract}
A new trend in the world community makes people aware of a healthy lifestyle, so start paying attention to food to be consumed. Organic vegetables are one of the natural food ingredients that are not contaminated by hazardous chemicals, but the buying action of Indonesian people towards organic vegetables is still low despite having high interest in organic vegetables, so do not follow the world trend. The purpose of this study was to analyze the factors that influence the intention of individuals in consuming organic vegetables by using TPB. The individual's intention in TPB is influenced by three factors: attitude, subjective norm and perception of behavior control. The research was conducted on mothers who were doing organic vegetable purchasing activity at Sayur dan Buah Store, Sawojajar Urban Village, Malang City using Structural Equation Modelling-Partial Least Square (SEM-PLS) method. The results of this study indicate that the variable attitude, subjective norms and behavior control perceptions give a significant influence on individual intentions in consuming organic vegetables with $p$ value $<0.001$. The value of $R$-square in this research is $51 \%$ means that the influence of attitude variable, subjective norm and perception of behavioral control toward organic vegetable purchasing intention is $51 \%$ while the remaining $49 \%$ is influenced by other variables outside the model.
\end{abstract}

Keywords: intention; organic vegetable; Theory of Planned Behavior; Partial Least Square (PLS)

How to cite:

Delviola, S., Anindita, R., \& Mutisari, R. (2018). Niat Individu Mengkonsumsi Sayur Organik di Kelurahan Sawojajar Kota Malang. Habitat, 29(1), 25-32. https://doi.org/10.21776/ub.habitat.2018.029.1.3 


\section{Pendahuluan}

Memasuki abad ke-21 terdapat sebuah tren baru yang menjadi perbincangan masyarakat dunia, yaitu mengenai slogan Back to Nature. Melalui tren tersebut maka masyarakat semakin meningkatkan kesadarannya terhadap gaya hidup sehat. Kini masyarakat semakin menyadari bahwa penggunaan pupuk kimia, pestisida kimia dan hormon pertumbuhan dalam pertanian dapat menimbulkan pengaruh negatif terhadap kesehatan manusia dan lingkungan (Bernardes et al., 2015). Bahaya penggunaan bahan kimia bagi kesehatan manusia menjadikan masyarakat semakin menjaga pola konsumsi dengan mengkonsumsi pangan yang alami tanpa mengandung bahan kimia yang berbahaya bagi kesehatan dan lingkungan.

Bahan pangan alami tanpa kandungan bahan kimia berbahaya dapat diperoleh melalui praktik pertanian organik. Pertanian organik merupakan kegiatan pertanian yang menjaga kelestarian lingkungan, tanah, tanaman, hewan dan manusia sebab semua termasuk dalam satu komponen yang saling berhubungan (Mayrowani, 2012). Salah satu produk pertanian organik yang dikembangkan dan dikenal oleh masyarakat adalah sayur. Sayur organik memiliki kandungan nitrat yang lebih rendah dibandingkan dengan sayur konvensional yang mengandung nitrat 97819\% (Winter \& Davis, 2006).

Semakin berkembangnya produk organik dan produsen organik di Indonesia dikarenakan adanya pengaruh gaya hidup masyarakat yang memperhatikan kesehatan dan lingkungan hidup dengan menggunakan produk organik. Namun perkembangan konsumsi pangan organik di Indonesia masih sangat terbatas karena konsumsi terhadap pangan organik hanya dilakukan oleh lapisan masyarakat tertentu yang sadar kesehatan dan kelestarian lingkungan (Reza et al., 2014).

Harga pangan organik yang relatif tinggi menjadi salah satu penyebab rendahnya konsumsi terhadap pangan organik, sehingga menyebabkan konsumen yang mengkonsumsi sayur organik tersegmentasi hanya pada konsumen yang memiliki tingkat pendapatan yang tinggi, sudah memiliki pengetahuan dan kesadaran terhadap hidup sehat. Pada umumnya, masyarakat yang memiliki tingkat pendapatan yang tinggi akan mengalihkan pola hidupnya menjadi pola hidup

\footnotetext{
${ }^{*}$ Penulis korespondensi

E-mail: suryadelviola13@gmail.com
}

sehat dengan mengkonsumsi makanan yang sehat, bergizi, mengandung vitamin dan aman dikonsumsi. Meningkatnya pendapatan masyarakat berdampak pada perubahan pola konsumsi pangan yaitu dengan mengurangi pangan sumber karbohidrat dan meningkatkan pangan sumber protein, vitamin dan mineral (Kementerian Perdagangan, 2013).

Konsumen sayur organik merupakan individu yang menentukan tindakan pembeliannya terhadap produk yang diinginkan. Faktor yang mempengaruhi konsumen dalam memilih suatu produk dipengaruhi oleh beberapa faktor yang berbeda. Menurut (Ajzen, 1991) untuk memprediksi niat konsumen dipengaruhi oleh tiga variabel yaitu sikap, norma subjektif dan persepsi kontrol perilaku. Niat konsumen dalam berperilaku dirumuskan dalam sebuah teori disebut dengan Theory of Planned Behavior (TPB). Oleh karena itu, penelitian ini dilakukan bertujuan untuk menganalisis variabel niat individu dalam mengkonsumsi sayur organik dengan mengaplikasikan Theory of Planned Behavior (TPB).

\section{Metode Penelitian}

Penelitian dilakukan di toko sayur dan buah Dapur Ku di jalan Danau Bratan Raya, Kelurahan Sawojajar, Kota Malang, Jawa Timur. Penelitian dilaksanakan pada bulan April 2018.

Penelitian yang dilakukan menggunakan pendekatan non probability sampling dengan metode accidental sampling. Responden dalam penelitian ini dilakukan pada ibu-ibu yang sedang melakukan pembelian sayur organik di toko sayur dan buah Dapur $\mathrm{Ku}$, kemudian di wawancarai menggunakan kuesioner. Jumlah sampel yang digunakan dalam penelitian ini sebanyak 50 responden.

\subsection{Evaluasi Model SEM - PLS}

a. Model Struktural (Structural Model) atau Pengaruh Variabel Laten Eksogen terhadap Variabel Laten Endogen

Model struktural dapat disebut juga dengan inner model, yaitu hubungan antar variabel yang dibangun berdasarkan teori. Persamaan inner model dalam penelitian ini, yaitu:

$\eta_{1}=\gamma_{1} \xi_{1}+\gamma_{2} \xi_{2}+\gamma_{3} \xi_{3}+\zeta_{1}$

Keterangan:

$\eta=$ Variabel niat

$\gamma_{1}=$ Koefisien variabel sikap

$\gamma_{2}=$ Koefisien variabel norma subjektif

$\gamma_{3}=$ Koefisien variabel persepsi kontrol perilaku 
$\xi_{1}=$ Variabel sikap

$\xi_{2}=$ Variabel norma subjektif

$\xi_{3}=$ Variabel persepsi kontrol perilaku

$\zeta_{1}=$ Galat dalam model

b. Model Pengukuran (Measurement Model) atau Pengaruh Indikator terhadap Variabel Laten

Model pengukuran dapat disebut juga dengan outer model yaitu untuk menggambarkan hubungan indikator dengan variabel. Persamaan outer model dalam penelitian ini, yaitu:

1) Variabel Laten Eksogen

$\mathrm{X}_{1.1}=\lambda_{x 1} \xi_{1}+\delta_{1}$

$\mathrm{X}_{1.2}=\lambda_{x 2} \xi_{1}+\delta_{2}$

$\mathrm{X}_{1.3}=\lambda_{x 3} \xi_{1}+\delta_{3}$

$\mathrm{X}_{1.4}=\lambda_{x 4} \xi_{1}+\delta_{4}$

$\mathrm{X}_{2.1}=\lambda_{x 5} \xi_{2}+\delta_{5}$

$\mathrm{X}_{2.2}=\lambda_{x 6} \xi_{2}+\delta_{6}$

$\mathrm{X}_{2.3}=\lambda_{x 7} \xi_{2}+\delta_{7}$

$\mathrm{X}_{3.1}=\lambda_{x 8} \xi_{3}+\delta_{8}$

$\mathrm{X}_{3.2}=\lambda_{x 9} \xi_{3}+\delta_{9}$

$\mathrm{X}_{3.3}=\lambda_{x 10} \xi_{3}+\delta_{10}$

$\mathrm{X}_{3.4}=\lambda_{x 11} \xi_{3}+\delta_{11}$

2) Variabel Laten Endogen

$Y_{1.1}=\lambda_{y 1} \eta_{1}+\varepsilon_{1}$

$Y_{2.1}=\lambda_{y 2} \eta_{1}+\varepsilon_{2}$

$Y_{3.1}=\lambda_{y 3} \eta_{1}+\varepsilon_{3}$

Keterangan:

$\xi_{1} \quad=$ Variabel sikap

$\xi_{2}=$ Variabel norma subjektif

$\xi_{3}=$ Variabel persepsi kontrol perilaku

$\eta \quad=$ Variabel niat

$\mathrm{X}_{1.1-1.4}=$ Indikator variabel sikap

$\mathrm{X}_{2.1-2.3}=$ Indikator variabel norma subjektif

$\mathrm{X}_{3.1-3.4}=$ Indikator variabel persepsi kontrol perilaku

$\mathrm{Y}_{1.1-3.1}=$ Indikator variabel niat

$\lambda_{x 1-x 4}=$ Koefisien indikator variabel sikap

$\lambda_{x 5-x 7}=$ Koefisien indikator variabel norma subjektif

$\lambda_{x 8-x 11}=$ Koefisien indikator variabel persepsi kontrol perilaku

$\lambda_{y 1-y 3}=$ Koefisien indikator variabel niat

$\delta_{1-11}=$ Galat indikator variabel laten eksogen

$\varepsilon_{1-3}=$ Galat indikator variabel laten endogen

c. Diagram Jalur

Setelah mengidentifikasi inner model dan outer model, maka tahap selanjutnya yaitu membuat diagram jalur atau path.

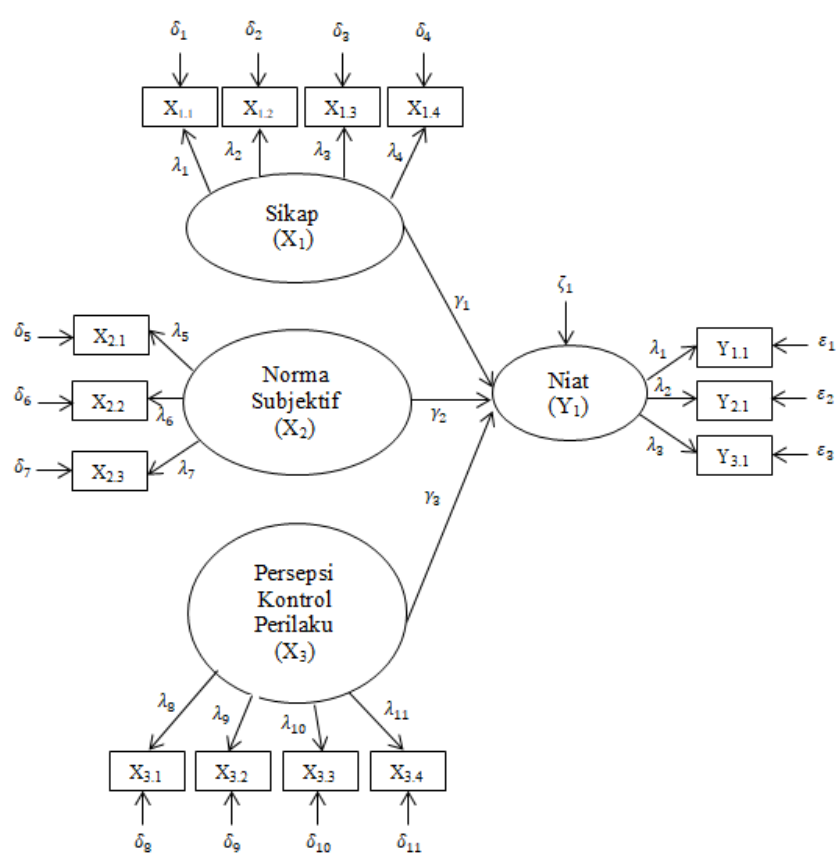

Gambar 1. Diagram Jalur Penelitian Sumber: (Hair et al., 2014)

Keterangan:

$\mathrm{X}_{1} \quad=$ Variabel sikap

$\mathrm{X}_{1.1}=$ Pembelian sayur organik tindakan bijaksana

$\mathrm{X}_{1.2}=$ Pembelian sayur organik ide yang baik

$\mathrm{X}_{1.3}=$ Sayur organik aman dikonsumsi

$\mathrm{X}_{1.4} \quad=$ Harga sayur organik lebih mahal dari sayur organik

$\mathrm{X}_{2} \quad=$ Variabel norma subjektif

$\mathrm{X}_{2.1}=$ Keluarga menginginkan pembelian sayur organik

$\mathrm{X}_{2.2} \quad=$ Orang yang penting senang bila saya membeli sayur organik

$\mathrm{X}_{2.3}=$ Teman dekat mendukung membeli sayur organik

$\mathrm{X}_{3} \quad=$ Variabel persepsi kontrol perilaku

$\mathrm{X}_{3.1} \quad=$ Keyakinan membeli sayur organik

$\mathrm{X}_{3.2}=$ Mampu membeli sayur organik meskipun mahal

$\mathrm{X}_{3.3}=$ Memiliki sumberdaya, waktu dan kesediaan membeli sayur organik

$\mathrm{X}_{3.4}=$ Memiliki kesempatan membeli sayur organik dimasa mendatang

$\mathrm{Y}_{1} \quad=$ Variabel niat

$\mathrm{Y}_{1.1}=$ Berniat membeli sayur organik karena memiliki kontribusi positif terhadap lingkungan

$\mathrm{Y}_{2.1} \quad=$ Berencana membeli lebih banyak sayur organik daripada anorganik

$\mathrm{Y}_{3.1}=$ Berpikir beralih membeli sayur organik karena alasan ekologis 
d. Evaluasi Model Pengukuran atau Pengaruh Indikator terhadap Laten

Pembentukan suatu variabel dapat dibentuk dengan indikator refleksif an fromatif. Pada penelitian ini hanya terdiri dari indikator refleksif. Evaluasi model pengukuran dengan variabel berbentuk refleksif terdiri dari beberapa tahapan yaitu indicator reliability, internal consistency reliability, convergent validity dan discriminant validity. Untuk mengukur reliabilitas indikator (indicator reliability) maka dapat dilihat dari nilai loading factor dengan nilai Rule of Thumb yaitu > 0,7. Evaluasi yang kedua adalah internal consistency reliability yaitu dengan melihat nilai dari composite reliability dengan ketentuan $>0,7$.

Evaluasi ketiga adalah convergent validity yaitu dengan melihat nilai dari AVE dengan ketentuan > 0,5. Nilai tersebut menunjukkan ukuran validitas konvergen yang baik dan memiliki arti bahwa variabel laten dapat menjelaskan rata-rata lebih dari setengah varian indikatornya. Evaluasi keempat adalah discriminant validity dengan melihat nilai cross loading yaitu dengan membandingkan nilai akar AVE pada variabel yang dituju dan harus lebih besar daripada korelasi antara variabel dengan variabel lainnya atau nilai AVE lebih tinggi dari kuadrat korelasi antara variabel.

e. Evaluasi Model Struktural atau Pengaruh Variabel Laten Eksogen terhadap Variabel Laten Endogen

Tahap untuk melakukan evaluasi model struktural terdiri dari:

1) Estimate for Path Coefficients merupakan tahap yang bertujuan untuk menunjukkan nilai signifikansi dari setiap koefisien jalur untuk mengetahui ada atau tidak pengaruh antar variabel yang dihipotesiskan dengan nilai $<0,05$.

2) Nilai $R^{2}$ merupakan koefisien determinasi pada variabel laten endogen. Nilai ini dapat digunakan untuk menjelaskan pengaruh variabel independen terhadap variabel dependen. Nilai $R^{2} \leq 0,70$ (model kuat), $\mathrm{R}^{2} \leq 0,45$ (model moderate) dan $\mathrm{R}^{2}$ $\leq 0,25$ (model lemah).

3) Effect Size $\left(\mathrm{f}^{2}\right)$ terbagi atas 3 klasifikasi yaitu $\geq 0.02$ (pengaruh kecil), $\geq 0.15$ (pengaruh moderat) dan $\geq 0.35$ (pengaruh besar). Nilai tersebut berarti bahwa variabel independen memiliki pengaruh kecil, menengah dan besar terhadap variabel dependen.
4) Predictive Relevance $\left(\mathrm{Q}^{2}\right)$ bertujuan untuk menunjukkan bahwa model memiliki predictive relevance atau kemampuan prediksi model. Nilai $\mathrm{Q}^{2}>0$ artinya variabel laten eksogen sesuai sebagai variabel penjelas yang mampu memprediksi variabel endogennya.

5) APC, ARS dan AARS memiliki nilai pvalue yang direkomendasikan yaitu $\leq$ 0,05 .

6) AVIF dan AFVIF, bertujuan untuk menguji masalah kolinearitas dengan ketentuan nilai harus $\leq 3,3$.

7) Tenenhaus Goodness of Fit (GoF) untuk memvalidasi model secara keseluruhan. Nilai GoF 0,1 (GoF kecil), 0,25 (GoF moderat) dan ),36 (GoF besar).

Langkah terakhir dari analisis data yaitu melakukan pengujian hipotesis. Pengujian hipotesis dilakukan dengan melihat nilai probabilitas. Kriteria penerimaan hipotesis dalam penelitian ini yaitu jika diperoleh nilai $p$-value $<$ 0,05 maka nilai tersebut signifikan sehingga menolak H0 dan menerima H1, artinya hipotesis diterima. Sedangkan jika diperoleh nilai $p$-value $>0,05$ maka nilai tersebut tidak signifikan sehingga menerima $\mathrm{H} 0$ dan menolak $\mathrm{H} 1$, artinya hipotesis tidak diterima. Berikut adalah hipotesis statistik dalam penelitian ini:

Hipotesis untuk outer model yaitu untuk melihat pengaruh indikator terhadap variabel laten sebagai berikut:

$\mathrm{HO}=\lambda_{i}=0$

$\mathrm{H} 1=\lambda_{i} \neq 0$

Hipotesis inner model yaitu pengaruh variabel laten eksogen dengan variabel laten endogen sebagai berikut:

$\mathrm{HO}=\gamma_{i}=0$

$\mathrm{H} 1=\gamma_{i} \neq 0$

\section{Hasil dan Pembahasan}

\subsection{Karakteristik Responden}

Responden yang dijadikan sebagai objek dalam penelitian ini merupakan ibu-ibu yang sedang melakukan pembelian sayur organik di Toko Dapur $\mathrm{Ku}$, Kelurahan Sawojajar, Kota Malang. Responden dalam penelitian ini didominasi oleh responden berusia 26 hingga 35 tahun yang berjumlah 18 orang dengan persentase sebanyak $36 \%$. Penelitian ini sesuai dengan penelitian yang dilakukan oleh Chrysanthini et al. (2017) bahwa responden yang 
mengkonsumsi sayur organik didominasi oleh perempuan berusia 20-35 tahun.

Menurut Sumarwan et al. (2013) usia 2635 tahun termasuk dalam kategori usia dewasa lanjut. Pada usia tersebut, individu lebih sensitif dengan isu lingkungan (Junaedi, 2003). Karakteristik responden berdasarkan pendidikan terakhir didominasi oleh responden S1 sebanyak 25 orang atau sebesar $50 \%$. Seseorang yang sudah menempuh pendidikan S1 dapat dikatakan sudah memiliki keputusan pembelian yang baik karena mempunyai informasi dan pengetahuan mengenai kualitas sebuah produk sehingga memilih sayur organik sebagai pilihan pembelian sayur di rumah tangganya (Sumarwan et al., 2013).

Karakteristik responden berdasarkan pekerjaan pada penelitian ini mayoritas memiliki pekerjaan sebagai ibu rumah tangga dengan jumlah sebanyak 21 orang atau persentase sebesar $42 \%$, artinya bahwa ibu rumah tangga memiliki peran yang besar sebagai pengambil keputusan pembelian sayur dirumah tangganya dan sangat menjaga kualitas pangan yang akan disajikan bagi keluarganya sehingga memilih sayur organik karena diyakini memiliki kualitas yang baik dan terhindar dari bahan kimia. Sedangkan karakteristik responden berdasarkan pendapatan didominasi oleh responden yang memiliki tingkat pendapatan sebesar Rp 2.600.000 hingga $\mathrm{Rp} 4.000 .000$ sebanyak 17 orang dengan persentase sebesar $34 \%$.

\subsection{Analisis Niat Individu Mengkonsumsi Sayur Organik}

\subsubsection{Pengaruh Indikator terhadap Variabel Laten}

Tahap pertama adalah nilai indicator reliability dapat dilihat berdasarkan nilai parameter loading factor. Nilai loading factor setiap indikator lebih besar dari 0,7 dan memiliki p-value $<0,05$. Berdasarkan nilai tersebut dapat diketahui bahwa indikator yang digunakan dalam penelitian ini telah memenuhi syarat nilai indicator reliability yang reliabel. Tahap kedua adalah internal consistency reliability yang dilihat dari parameter composite reliability yang menunjukkan nilai $>0,7$, hal ini berarti setiap variabel konsisten dalam mengukur konstruk.

Tahap ketiga adalah convergent validity yang dilihat nilai average variance extract (AVE) dan sudah memenuhi kriteria yaitu lebih besar dari 0,5 yang berarti bahwa setiap variabel sudah memiliki validitas konvergen yang baik. Tahap keempat adalah melihat nilai discriminant validity harus memenuhi kriteria yaitu akar kuadrat AVE harus lebih besar dari korelasi antar variabel dalam model. Hasil menunjukkan nilai akar kuadrat AVE dari setiap variabel lebih besar dari korelasi variabelnya. Oleh sebab itu dapat dikatakan bahwa seluruh variabel memiliki validitas diskriminan yang baik.

\subsubsection{Pengaruh Variabel Laten Eksogen terhadap Variabel Laten Endogen}

\section{a. Estimate for Path Coefficients}

Koefisien jalur bertujuan untuk melihat ada atau tidaknya pengaruh antar variabel. Variabel sikap terhadap variabel niat memiliki nilai koefisien jalur sebesar 0,47 dan signifikan pada $p$-value $<0,01$. Hal ini berarti bahwa sikap terhadap pembelian sayur organik berpengaruh positif terhadap niat pembelian sayur organik sebesar 0,47. Koefisien jalur yang terbentuk antara variabel norma subjektif terhadap variabel niat adalah sebesar 0,23 dengan taraf signifikansi $5 \%$ pada $p$-value 0,04 . Kemudian koefisien jalur yang terbentuk antara variabel persepsi kontrol perilaku terhadap niat adalah sebesar 0,25 dengan signifikansi $p$-value 0,03 .

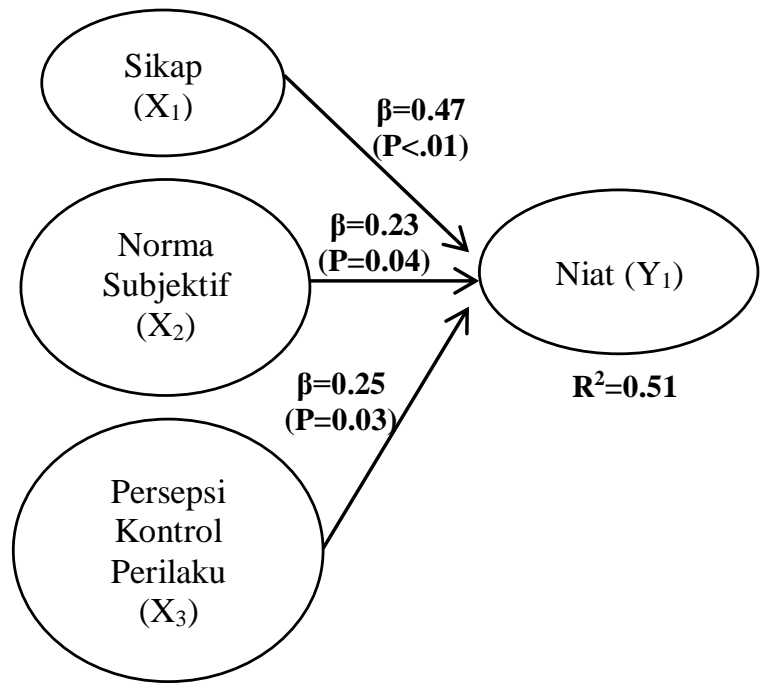

Gambar 2. Coefficient Path dan p-value

b. R-square

Hasil penelitin menunjukkan nilai Rsquare sebesar 0,510 artinya bahwa pengaruh variabel sikap, norma subjektif dan persepsi kontrol perilaku terhadap niat pembelian sayur organik adalah sebesar $51 \%$ dan sisanya sebesar $49 \%$ dipengaruhi oleh variabel lain di luar model penelitian ini.

\section{c. $\quad Q^{2}$ Predictive Relevance}

Nilai $Q$-squared yang diperoleh dalam penelitian ini adalah sebesar 0,509. Hal ini berarti 
bahwa model memiliki predictive relevance karena nilai $\mathrm{Q}^{2}>0$ yaitu sebesar 0,509.

Tabel 1. Nilai $R$-squared dan $Q$-squared

\begin{tabular}{ccccc}
\hline & $\mathrm{X} 1$ & $\mathrm{X} 2$ & $\mathrm{X} 3$ & $\mathrm{Y} 1$ \\
\hline R-squared & & & & 0,510 \\
Q-squared & & & & 0,509 \\
\hline
\end{tabular}

d. APC, ARS, AVIF, Goodness of Fit (GoF)

Berdasarkan hasil, nilai APC adalah sebesar 0,320 dengan $p$-value 0,003 , ARS dengan nilai 0,510 dengan $p$-value $<0,001$, hal ini berarti bahwa model telah memenuhi kriteria model fit dengan level signifikansi $<0,05$. Kemudian nilai AVIF adalah sebesar 1,193 yang artinya bahwa dalam model penelitian ini tidak terjadi kolinearitas antar indikator dan antar variabel laten karena telah memenuhi syarat yaitu $\leq 3,3$. Melalui hasil analisis data yang dilakukan diperoleh nilai GoF sebesar 0,611 yang berarti bahwa goodness of fit model ini tinggi karena nilainya $\geq 0,36$ dan dianggap layak.

Tabel 2. Nilai Average Path Coefficient (APC), Average $R$-Squared (ARS), Average block VIF (AVIF) dan Goodness of Fit (GoF)

\begin{tabular}{lcc}
\hline & Nilai & p-value \\
\hline $\begin{array}{l}\text { Average path coefficient } \\
\text { (APC) }\end{array}$ & 0,320 & 0,003 \\
$\begin{array}{l}\text { Average R-squared (ARS) } \\
\begin{array}{l}\text { Average block VIF } \\
\text { (AVIF) }\end{array}\end{array}$ & $1,1930,001$ \\
$\begin{array}{l}\text { Tenenhaus Goodness of } \\
\text { Fit (GoF) }\end{array}$ & 0,611 & \\
\hline
\end{tabular}

3.3. Pembahasan Terkait Pengaruh Sikap, Norma Subjektif dan Persepsi Kontrol Perilaku terhadap Niat Individu Mengkonsumsi Sayur Organik

\subsubsection{Sikap terhadap Niat Mengkonsumsi Sayur Organik}

Hasil analisis data dalam penelitian ini menunjukkan bahwa sikap individu memberikan pengaruh yang positif dan signifikan terhadap niat individu dalam mengkonsumsi sayur organik. variabel sikap memiliki nilai $p$-value sebesar $<0,001$ yang berarti signifikan pada taraf signifikansi $5 \%$, artinya bahwa $\mathrm{H} 1$ diterima dengan nilai $\gamma \neq 0$ yang dibuktikan oleh nilai koefisien jalur sebesar 0,474. Hal ini berarti bahwa sikap memiliki pengaruh positif dan signifikan terhadap niat pembelian sayur organik. Berdasarkan model TPB, dari ketiga variabel yang memengaruhi niat dalam berperilaku, sikap merupakan variabel yang berpengaruh paling besar terhadap niat mengkonsumsi sayur organik.

Penelitian ini sejalan dengan penelitian yang telah dilakukan oleh Wijaya, (2014), Basha et al. (2015) dan Eles dan Sihombing (2016) yang menyatakan bahwa niat pembelian konsumen terhadap pangan organik dipengaruhi oleh sikap. Berdasarkan penelitian terdahulu tersebut terdapat beberapa alasan yang mendorong konsumen memiliki sebuah sikap yang positif terhadap sayur organik yaitu karena kepedulian terhadap lingkungan, kepedulian masyarakat terhadap kesehatan dan pengalaman masyarakat yang sudah pernah mengkonsumsi sayur organik sehingga memberi sikap yang positif.

Responden yang melakukan pembelian terhadap sayur organik di Toko Sayur Dapur Ku juga memiliki penilaian yang positif terhadap sayur organik karena menurut responden tersebut membeli sayur organik merupakan tindakan yang bijaksana, ide yang baik, karena sayur organik aman dikonsumsi dan tidak tercemar oleh bahanbahan kimia. Responden dalam penelitian ini didominasi oleh ibu-ibu yang berpendidikan S1 sebanyak 50\%. Tingkat pendidikan dapat mempengaruhi seseorang untuk mengenal kebutuhan dan keputusan pembeliannya. Seseorang yang berpendidikan tinggi memiliki kemampuan yang tinggi untuk menerima dan memahami informasi yang diterimanya.

\subsubsection{Norma Subjektif terhadap Niat Mengkonsumsi Sayur Organik \\ Variabel norma subjektif dalam penelitian} ini memberikan pengaruh yang positif terhadap niat individu dalam mengkonsumsi sayur organik yang ditunjukkan dengan nilai $p$-value sebesar 0,038 atau signifikan pada taraf $5 \%$, hal ini berarti bahwa $\mathrm{H} 1$ diterima dengan nilai $\gamma \neq 0$ yang ditunjukkan dengan nilai koefisien jalur sebesar 0,234. Hal ini menunjukkan bahwa norma subjektif memberikan pengaruh nyata terhadap niat individu dalam mengkonsumsi sayur organik. Namun, norma subjektif merupakan variabel yang memberikan pengaruh terendah yang mempengaruhi niat individu mengkonsumsi sayur organik dalam penelitian ini.

Penelitian ini sesuai dengan penelitian yang dilakukan oleh Al-Swidi et al. (2014), Teng dan Wang (2015) dan Maichum et al. (2016) bahwa norma subjektif memberikan pengaruh yang signifikan terhadap niat individu dalam 
mengkonsumsi sayur organik meskipun hanya memberikan pengaruh yang kecil. Indikator norma subjektif dalam penelitian ini antara lain keluarga, orang yang penting bagi konsumen (tetangga, dokter dan rekan kerja) dan teman dekat. Berdasarkan hasil penelitian yang telah dilakukan pada variabel norma subjektif, indikator orang yang penting bagi responden memiliki pengaruh yang paling tinggi dibandingkan indikator lain dalam variabel norma subjektif. Orang yang penting bagi responden dalam penelitian ini merupakan tetangga, rekan kerja dan dokter.

\subsubsection{Persepsi Kontrol Perilaku terhadap Niat Mengkonsumsi Sayur Organik}

Persepsi kontrol perilaku merupakan mudah atau sulitnya seseorang dalam mewujudkan sesuatu. Hasil dari analisis data yang dilakukan dalam penelitian ini menunjukkan bahwa variabel persepsi kontrol perilaku memberikan pengaruh yang positif terhadap niat individu mengkonsumsi sayur organik. Hal ini ditandai dengan nilai p-value sebesar 0,028 artinya variabel ini signifikan pada taraf 5\%, sehingga $\mathrm{H} 1$ diterima dengan nilai $\gamma \neq$ 0 yang ditunjukkan dengan koefisien jalur sebesar 0,251. Dengan demikian maka persepsi kontrol perilaku signifikan terhadap niat mengkonsumsi sayur organik dan memberikan pengaruh terbesar kedua terhadap niat mengkonsumsi sayur organik setelah variabel sikap.

Penelitian ini sejalan dengan penelitian yang telah dilakukan oleh Maichum et al. (2016) yang menyatakan bahwa variabel persepsi kontrol perilaku memberikan pengaruh yang signifikan terhadap niat individu mengkonsumsi pangan organik. Seseorang yang memiliki kontrol perilaku yang kuat maka akan memiliki niat membeli sayur organik semakin tinggi, sebaliknya jika kontrol perilaku lemah maka niat individu dalam mengkonsumsi sayur organik rendah. Berdasarkan hasil wawancara yang telah dilakukan pada responden yang melakukan pembelian sayur organik di Toko Sayur Dapur $\mathrm{Ku}$, responden tersebut menyatakan bahwa mereka memiliki keyakinan atau kepercayaan bahwa sayur organik merupakan sayur yang tidak terkontaminasi terhadap bahan kimia, aman dikonsumsi dan memiliki kualitas yang baik. Oleh sebab itu responden lebih memilih untuk melakukan pembelian terhadap sayur organik dibandingkan dengan sayur anorganik.

\section{Kesimpulan}

Berdasarkan hasil analisis yang telah dilakukan, maka kesimpulan dalam penelitian ini yaitu, variabel sikap memberikan pengaruh yang positif dan signifikan dan merupakan variabel yang paling berpengaruh terhadap niat individu dalam mengkonsumsi sayur organik. Responden menyatakan pembelian terhadap sayur organik merupakan tindakan yang bijaksana, responden sudah yakin bahwa sayur organik aman dikonsumsi, harganya lebih mahal dibandingkan sayur anorganik dan pembelian terhadap sayur organik merupakan sebuah ide yang baik.

Variabel norma subjektif dalam penelitian ini memberikan pengaruh yang positif dan signifikan, namun merupakan variabel yang paling kecil pengaruhnya terhadap niat mengkonsumsi sayur organik. Responden menyatakan bahwa orang yang penting bagi responden seperti tetangga, rekan kerja dan dokter memberikan pengaruh yang besar untuk mengkonsumsi sayur organik.

Variabel persepsi kontrol perilaku juga memberikan pengaruh yang positif dan signifikan dan merupakan variabel yang memberikan pengaruh terbesar kedua setelah variabel sikap terhadap niat dalam mengkonsumsi sayur organik. Responden dalam penelitian ini menyatakan mampu membeli sayur organik meskipun memiliki harga yang mahal, memiliki sumberdaya, waktu dan kesediaan untuk membeli sayur organik, memiliki keyakinan dapat membeli sayur organik dibandingkan sayur anorganik dan responden menyatakan memiliki kesempatan untuk membeli sayur organik dimasa mendatang.

Saran yang diberikan dalam penelitian ini adalah:

a. Berdasarkan aspek sikap diperlukan adanya peran aktif dari pemerintah untuk mengajak masyarakat mengkonsumsi sayur organik dengan melakukan kampanye berupa penyuluhan dan pembelajaran kepada ibu-ibu PKK di tiap wilayah mengenai manfaat dan kualitas sayur organik.

b. Dari aspek norma subjektif, orang yang penting bagi responden seperti tetangga, rekan kerja dan dokter memiliki peranan yang paling besar dalam mempengaruhi responden membeli sayur organik, dengan demikian disarankan untuk selalu memberikan dorongan kepada responden 
agar sayur organik menjadi prioritas pembelian sayur dalam keluarganya.

c. Berdasarkan aspek persepsi kontrol perilaku, disarankan agar pemerintah mulai untuk mencanangkan budidaya pertanian organik bagi petani sayur sehingga semakin banyak petani sayur organik maka jumlah dan jenis sayur organik yang dipasarkan semakin banyak dan harga yang ditawarkan kepada konsumen tidak terlalu tinggi. Dengan demikian, sayur organik dapat selalu tersedia di toko sayuran maupun di pasar tradisional agar dapat memenuhi permintaan konsumen.

d. Peneliti memberikan saran kepada penelitian selanjutnya agar melakukan penelitian yang sama untuk meneliti perilaku individu dalam mengkonsumsi sayur organik dengan menambahkan variabel lain seperti kesadaran terhadap kesehatan, pengetahuan tentang lingkungan dan kesediaan membayar.

\section{Daftar Pustaka}

Ajzen, I. (1991). The theory of planned behavior. Organizational Behavior and Human Decision Processes, 50(2), 179-211.

Al-Swidi, A., Huque, S. M. R., Hafeez, M. H., \& Shariff, M. N. M. (2014). The role of subjective norms in theory of planned behavior in the context of organic food consumption. British Food Journal, 116(10), 1561-1580.

Basha, M. B., Mason, C., Shamsudin, M. F., Hussain, H. I., \& Salem, M. A. (2015). Consumers Attitude Towards Organic Food. Procedia Economics and Finance, 31(15), 444-452.

Bernardes, M. F. F., Pazin, M., Pereira, L. C., \& Dorta, D. J. (2015). Impact of Pesticides on Environmental and Human Health. Toxicology Studies.

Chrysanthini, B., Sumarwan, U., \& Rifin, A. (2017). Preferensi Konsumen terhadap Produk Sayuran Organik ( Studi Kasus Konsumen UD Fabela-Myfarm ) di Bogor Jawa Barat. Manajemen IKM IPB, 12(2), 151-160.

Eles, S. F., \& Sihombing, S. O. (2016). Determinan Niat Beli Makanan Organik: Sikap Untuk Membeli Sebagai Variabel Mediasi. Jurnal Ilmiah Manajemen, VI(3),
313-332.

Hair, J. F., Sarstedt, M., Hopkins, L., \& G. Kuppelwieser, V. (2014). Partial least squares structural equation modeling (PLSSEM). European Business Review, 26(2), 106-121.

Junaedi, M. F. S. (2003). Analisis Faktor Demografi, Akses Media dan Sumber Informasi terhadap Kepedulian dan Kesadaran Lingkungan Konsumen: Kajian Pemasaran yang Berwawasan Sosial. Kinerja, 7(2), 96-111.

Kementerian Perdagangan. (2013). Analisis Dinamika Konsumsi Pangan Masyarakat Indonesia. Pusat Kebijakan Perdagangan Dalam Negeri, 1, 67.

Maichum, K., Parichatnon, S., \& Peng, K.-C. (2016). Application of the Extended Theory of Planned Behavior Model to Investigate Purchase Intention of Green Products among Thai Consumers. Sustainability, $8(10), 1077$.

Mayrowani, H. (2012). Pengembangan Pertanian Organik Di Indonesia The Development Of Organic Agriculture In Indonesia. Forum Penelitian Agro Ekonomi, 30(2), 91-108.

Reza, S., Devi, M., \& Hartono, G. (2014). Faktor-Faktor Yang Mempengaruhi Keputusan Konsumen Dalam Membeli Sayuran Organik Factors Affecting Consumers Decision in Buying Organic Vegetables. Agric, 27(12), 60-67.

Sumarwan, U., Noviandi, A., \& Kirbrandoko. (2013). Analisis Proses Keputusan Pembelian, Persepsi dan Sikap Konsumen Terhadap Beras Organik di Jabotabek. Pangan, 22(2), 19-35.

Teng, C.-C., \& Wang, Y.-M. (2015). Decisional factors driving organic food consumption. British Food Journal, 117(3), 1066-1081.

Wijaya, T. (2014). Nilai Dan Pengetahuan Sebagai Prediktor Intensi Beli Makanan Organik. Jurnal Manajemen Dan Kewirausahaan, 16(1), 69-81.

Winter, C. K., \& Davis, S. F. (2006). Organic foods. Journal of Food Science, 71(9), 117124. 